\title{
Jesus of Nazareth
}





\title{
Jesus of Nazareth
}

\section{JÜRGEN BECKER}

\author{
Translated by \\ James E. Crouch
}

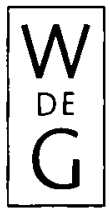

WALTER DE GRUYTER NEW YORK • BERLIN 